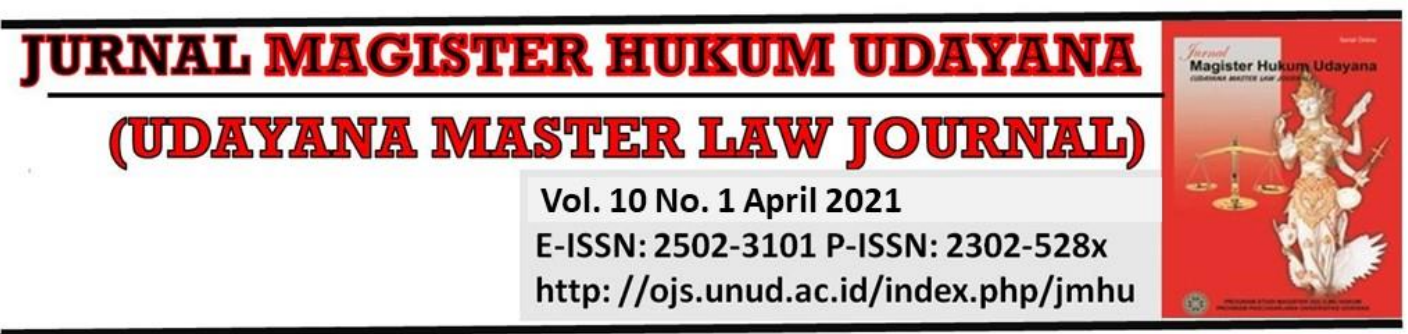

\title{
Determination of the Benoa Bay Maritime Conservation Area in the Effectiveness of Environmental Maintenance
}

\author{
Mega Rasnawati ${ }^{1}$, Putu Gede Arya Sumerta Yasa ${ }^{2}$ \\ ${ }^{1}$ Law Firm Togar Situmorang, E-mail: mrasnawati@gmail.com \\ ${ }^{2}$ Faculty of Law, Udayana University, E-mail: $\underline{\text { arya_sumerthayasa@unud.ac.id }}$
}

\begin{tabular}{l}
\hline Info Article \\
\hline Received: $25^{\text {th }}$ August 2020 \\
Accepted: $4^{\text {th }}$ April 2021 \\
Published: $9^{\text {th }}$ April 2021 \\
Keywords: \\
Conservation, Reclamation, \\
Benoa Bay \\
Corresponding Author: \\
Mega Rasnawati, \\
E-mail: mrasnawati@gmail.com \\
DOI: \\
10.24843/JMHU.2021.v10.i01. \\
p04
\end{tabular}

\begin{tabular}{l} 
Abstract \\
\hline Reclamation based on the revitalization of Benoa Bay-Bali which \\
is regulated in Presidential Decree No. 51 of 2014 has the goal of \\
increasing competitiveness in the field of tourism destinations. \\
However, many Balinese people reject the reclamation of Benoa \\
Bay-Bali because the Benoa Bay area is a conservation area. With \\
various objections from the Balinese people, KEPMEN KP No: \\
$46 / K E P M E N-K P / 2019$ was issued regarding the management of \\
the maritime cultural protection area of Benoa Bay-Bali by \\
appointing the Bali Provincial Government as the manager. This \\
study aims to examine policies regarding the maritime \\
conservation area of Benoa Bay-Bali managed by the Provincial \\
Government of Bali, as well as the determination of the Benoa \\
Bay-Bali maritime conservation area to function effectively in the \\
framework of environmental preservation. Using sociolegal \\
research with a statutory approach and a case approach. The \\
result of the research is that there is no further regulation \\
regarding the Bali Provincial Regulation regarding the \\
management of the Benoa Bay maritime conservation area, so \\
that there is a norm vacuum. It is hoped that the determination of \\
the Benoa Bay maritime conservation area to be able to effectively \\
provide a positive impact in environmental maintenance \\
activities, in which to ensure its wise use and increase the quality \\
of its value and diversity.
\end{tabular}

\section{Introduction}

The Island of Gods Bali is one of Indonesia's tourism icons that can attract foreign tourists. Bali has three main elements which are very typical characteristics compared to other regions, such as its nature, society (culture), and religion. ${ }^{1}$

In this case, Bali, cannot be separated from development which is directed at economic development in the tourism sector which is based on the culture of the Balinese people. Development in principle is human effort in exploiting the environment and natural resources in order to improve the standard of human life itself, and not inversely proportional to where the development is actually detrimental to the survival of living things, so it is hoped that all types of development can apply the sustainable development principles. Sustainable development in Article 1 paragraph (3) of Law Number 32 Year 2009 concerning Environmental Protection and Management

${ }^{1}$ Dikdik Adiarsa, “Efektivitas Tata Hutan Di Kawasan Hutan Lindung Gunung Seraya Dalam Upaya Mengakomodir Kepentingan Religi", Kertha Patrika 40, no 01 (2018): 24-36. 
(hereinafter referred to as the PPLH Law) can be interpreted as a form of development which does not undermine the capacity of future generations in terms of their development. This should serve as a guideline, even though there has been a decrease in natural resource reserves and environmental conditions that are increasingly worrisome, but it can still be renewed with other resources, either by human resources or by capital resources. ${ }^{2}$ In addition, the values within Pancasila as the nation's philosophy of life need to be implemented to arouse the nation's fighting spirit, not only to solve the problem of economic downturn, but also to improve the quality of human resources in Indonesia. ${ }^{3}$

With regard to economic development, Presidential Regulation Number 51 of 2014 concerning Amendments to Presidential Regulation No. 45 of 2011 concerning the Urban Spatial Plan for Denpasar, Badung, Gianyar, and Tabanan (hereinafter referred to as Perpres No. 51/2014) which was issued during the term of office of the 6th Indonesian president, Susilo Bambang Yudhoyono, which in the regulation is in the beginning, Benoa Bay had a conservation status and now the status of the area has been changed into an area that can be used for public interest. The issuance of Presidential Decree No. 51/2014 is solely to cover the reclamation activities of Benoa Bay which covers an area of 700 ha, by eliminating Article 55 paragraph (5), which states "Benoa Bay as a conservation area", and turning it into a buffer zone in the provisions of Article 63A paragraph (2), so that reclamation is now permisible. Various aspects that will be generated from reclamation activities, namely, including environmental, socio-cultural and economic aspects. The polluted and impacted environment of reclamation is a necessity, while cultural life can also be threatened due to the loss of open space that has naturally been enjoyed by people in coastal areas, especially the economic side of the community, to be more specific, the fishermen who will lose their livelihoods due to the reclamation project.. ${ }^{4}$

The number of strong objections from the community who joined the ForBALI forum which began in 2012, when the Governor of Bali Province at that time, Mangku Pastika, gave permission and the right to use the Benoa Bay area to PT. TWBI in Decree No: 2138/02-C/HK/2012. According to the Balinese, the Decree was problematic, because it did not involve the community in the study of making the SK, especially those who live on the coast of Benoa Bay, so the Governor of Bali Province was considered not transparent in granting permits to PT. TWBI. ${ }^{5}$ Especially in the environmental impact analysis document (AMDAL) owned by PT. TWBI is not transparent in accordance with the Report Specific Work Visit Of Commission IV The House of Representatives of The Republic of Indonesia to the Bali Province, In The Session Period I Of The 20192020, 28-30 November 2019, which should involve the community in accordance with Article 26 of the PPLH Law. Sjachran Basah stated that a permit is defined as "a legal

2 Syukri Hidayatullah, "STANDARDISASI INDUSTRI NASIONAL DALAM MEWUJUDKAN PEMBANGUNAN BERKELANJUTAN", Kertha Patrika 38, no 2 (n.d.).

3 Iwan Nugroho, "Nilai-nilai Pancasila sebagai falsafah pandangan hidup bangsa untuk peningkatan kualitas sumber daya manusia dan pembangunan lingkungan hidup", Jurnal Konstitusi 3, no 2 (2010).

4 Francisca, M., \& Roberto, I. (2018). Kelestarian Lingkungan Sumber Daya Alam Kelautan Dalam Implikasi Reklamasi Laut. Legality: Jurnal Ilmiah Hukum, 25(1), 59-68. doi: https://doi.org/10.22219/jihl.v25i1.5989, p. 64-65

5 Wayan Suantika, "Resistensi Masyarakat Lokal terhadap Kapitalisme Global: Studi Kasus Reklamasi Teluk Benoa Bali Tahun 2012-2013", Jurnal Hubungan Internasional, 2015, 55. 
act of one-sided state administration that applies regulations in concrete terms based on statements and procedures as stipulated by the provisions of legislation." 6 Permit is a government instrument that is juridical preventive in nature, which is used as a means of administrative law to control public behavior.

The Balinese people showed even more rejection when the Decree of the Governor of Bali Province contradicted Presidential Decree No. 45/2011 which states "Benoa Bay is a conservation area that cannot be used or reclaimed." However, in its sustainability, the government approved the Benoa Bay reclamation plan by making changes to Presidential Decree No. 45/2011 becomes Presidential Decree No. 51/2014, where the status of Benoa Bay directly changed to a highly usable cultivation area, this has provided the green light for the implementation of the reclamation project. This made the Balinese people suspicious of a conspiracy behind these policies, so they also demanded the immediate repeal of Presidential Decree No. 51/2014 by holding a ForBali demonstration or peaceful demonstration in front of government agencies, and sending proposals regarding the seriousness of the community in rejecting the project based on logical reasons. ${ }^{7}$

Seeing For BALI's struggle against the existence of Benoa Bay reclamation activities/projects from the beginning of the issuance of Presidential Decree Number 51 of 2014 until recently, the Governor of Bali Province-who was elected in 2018, I Wayan Koster, sent a letter from the Governor of Bali to the Minister of Marine Affairs and Fisheries of the Republic of Indonesia Number: 523.32/1687/KL/DISLAUTKAN dated 11 September 2019 regarding the Proposal for the Establishment of a Benoa Bay Maritime Conservation Area. The Minister of Marine Affairs and Fisheries of the Republic of Indonesia responded to the Bali Governor's Decree by issuing KEPMEN KP No: 46/KEPMEN-KP/2019 concerning the Benoa Bay Maritime Conservation Area in the Waters of the Province of Bali which was stipulated on 4 October 2019 (hereinafter referred to as Kepmen-KP No. 46/2019). In the Decree of the Minister of Kalimantan and Fisheries, the Regional Government of Bali Province ordered the management of the Benoa Bay maritime cultural protection area, which is considered to bring a little fresh air, even though the above regulation, namely Presidential Decree Number 51 of 2014 has not been revoked as the basis for allowing the Benoa Bay reclamation project to continue.

Based on this background description, two issues can be raised: 1) How is the arrangement of the Benoa Bay maritime conservation area managed by the Bali Provincial Government? 2) Can the determination of the Benoa Bay maritime conservation area be effective in preserving the environment?

The purpose of this research is to find out and analyze the Benoa Bay maritime conservation area policy managed by the Bali Provincial Government, as well as the determination of the Benoa Bay maritime conservation area to function effectively in the context of environmental preservation.

In this case the author assures that there is no plagiarism element, as proof of differentiation, other scientific works will be included, namely the scientific work

\footnotetext{
${ }^{6}$ Ridwan Hr, “Hukum administrasi negara”, Jakarta: Raja Grafindo Persada, 2006.

7 Wayan Suantika, op.cit, p. 56
} 
entitled Setting the Beach as a Sacred Area in Providing Tirta Tourism Facilities in Bali Province, by I Nyoman Adi Susila, with the formulation of the problem: 1 ). How is the arrangement of the sacred coastal area in the provision of water tourism facilities in Bali Province?, And 2). How is the implementation of arrangements for the sacred coastal area in the provision of water tourism facilities in Bali? ${ }^{8}$ And a study entitled Legal Efforts to Settle a Dispute on Marine Environment Pollution in the Case of the Montara Oil Spill in the Timor Sea, by Ni Putu Suci Meinarni, with the following problem statements: 1). How can the dispute resolution be pursued in the case of

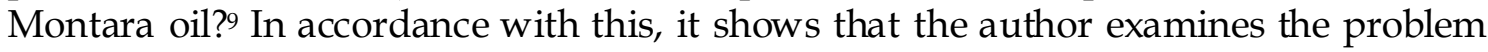
with a title that has never been done in the same research before.

\section{Research Methods}

Using the type of sociolegal research. Sociolegal can be defined as legal studies that use both legal and social science approaches, by explaining the relationships and links where the law applies. Statute Approach and Case Approach are the approaches applied in conducting this research. Using primary legal material sources in the form of statutory regulations and secondary sources of law, namely in the form of related literature in accordance with the problem. The snow ball technique is used in the collection of legal materials. Analysis of legal materials using the method of description, evaluation and argumentation.

\section{Result and Discussion}

\subsection{The arrangement of the Benoa Bay Maritime Conservation Area which is managed by the Bali Provincial Government}

Article 1 number 23 of Law No. 1 of 2014 concerning Management of Coastal Areas and Small Islands states "Reclamation is an activity carried out by people in order to increase the benefits of land resources from an environmental and socio-economic point of view by means of land filling, draining or drainage". In connection with the Benoa Bay reclamation project, which from the beginning received a lot of strong resistance from ForBALI and asked for Presidential Decree No. 51/2014 to be immediately withdrawn, with 13 reasons in strong rejection of the Benoa Bay reclamation project, which are: 10

1. Removal of the conservation function;

2. Water Overflow;

3. Natural Disasters;

4. Destruction of coral; reefs;

5. The mangrove ecosystem is threatened;

6. Beach Erosion;

\footnotetext{
8 I Nyoman Adi Susila, "Pengaturan Kawasan Suci Pantai Dalam Penyediaan Sarana Wisata Tirta Di Provinsi Bali", Jurnal Magister Hukum Udayana (Udayana Master Law Journal) 6, no 4 (2017): 478-88.

${ }^{9} \mathrm{Ni}$ Putu Suci Meinarni, "PENYELESAIAN SENGKETA PENCEMARAN LINGKUNGAN LAUT DALAM KASUS TUMPAHAN MINYAK MONTARA DI LAUT TIMOR", Jurnal Magister Hukum Udayana (Udayana Master Law Journal) 5, no 4 (2016): 833-70.

10 "13 Alasan Tolak Reklamasi Teluk Benoa - ForBALI", n.d.
} 
7. Widespread ecological disaster

8. Cheapening the price of land

9. Regulations that benefit investors

10. Uneven Development

11. False promises of investor

12. Breaking Commitmen of CTI (Coral Triangle Initiative)

13. Decline in tourism in Bali.

Siding with the Balinese people who strongly reject the reclamation of Benoa Bay, the Minister of Marine Affairs and Fisheries in Kepmen-KP No. 46/2019 in the fifth part of the Ministerial Decree states that the management of the Benoa Bay Maritime Cultural Protection Area, which is located in the waters of Bali Province, includes the appointment of a management organization, preparation and stipulation of management plans and zoning regulations for Maritime Conservation Areas, delineation of boundaries, conducting socialization and strengthening of management is submitted and implemented by the Bali Provincial Government. Based on this, the Benoa Bay reclamation project should not have been able to proceed because of the designation of the Benoa Bay area as a maritime conservation area, even though the above regulation is Presidential Decree No. 51/2014 has not been revoked as a legal basis for allowing the reclamation of Benoa Bay, can be related to the Theory of Legal Preference which designates which law takes precedence to apply, if in an event the law is related or subject to several regulations. Such as the Principle of Lex Posterior Derogat Legi Priori, where this principle has an existence to remember new laws and regulations that represent ongoing situations and needs. With regard to authority in the management of coastal areas and small islands, it can be implemented properly, if it is based on values, principles and norms in a harmonious atmosphere without causing conflict. ${ }^{11}$

There are four theories used in this problem regarding the develop environmental law, namely: 12

1. The economic account

In the context of the application of this theory in environmental law that sees natural resources it can be compared with material, which is based on the idea that the source of environmental problems is the scarcity of natural resources and failure in marketing.

2. Rights account

The state has the right to punish acts that have an impact on environmental pollution and destruction, through environmental law instruments, which also strongly obliges business actors to reduce the level of pollution and damage which is the impact of their business activities.

3. The partenalism account

This theory has the meaning that where the position of the state is seen as a parent, and society as a child, so that the state has the responsibility to educate and direct its citizens, namely by directing the community to

11 Syifaur Rahmah, "PERLINDUNGAN HUKUM TERHADAP HAK MASYARAKAT NELAYAN WILAYAH PESISIR", Dinamika: Jurnal Ilmiah Ilmu Hukum 25, no 10 (2019).

12 Richard Stewart en James E Krier, “Environmental Law and Policy, New York: The Bobbs Merril Co", Indianapolis, hlm, 1978,3-5. 
change bad habits that have an impact on the environment into positive things that are liked so that can also be useful for community welfare.

4. Public values account

Deliberative process which is based on the nature of open-mindedness and accepting constructive criticism is the basis for joint decision-making in rational decision-making.

Associated with the theory of rights through regulations in environmental law, the state can impose sanctions on actions that could harm environmental ecosystems. Environmental protection and management in the provisions of Article 1 paragraph (2) of the PPLH Law is an effort carried out in a systematic and integrated manner to preserve environmental functions and prevent environmental pollution or damage which includes planning, maintenance, utilization, control, supervision, and of course enforcement law. This is carried out by referring to the principles contained in Article 2 of the PPLH Law. Law in the formulation stage of its policies until the implementation stage contains partiality for the weakest party in the structure of society, where such a legal system is a moral imperative of the teachings of the Constitution and the ideology of Pancasila. ${ }^{13}$

The maritime conservation area which has been determined by the existence of Kepmen-KP No. 46/2019 is a form of environmental maintenance through conservation of natural resources, in accordance with Chapter VI concerning Maintenance in Article 57 of the PPLH Law as well as in Chapter VI concerning Maintenance in Article 41 of the Bali Provincial Regulation Number 1 of 2017 (hereinafter referred to as Perda Bali Province No.1 / 2017). Environmental preservation according to Article 57 of the PPLH Law is an effort carried out in order to maximize the preservation of environmental functions, as well as prevent damage caused by human actions, one of which is the impact of the Benoa Bay reclamation project. Conservation of Natural Resources is the management of natural resources itself to remain consistent in ensuring its wise use by always paying attention to, maintaining and increasing the quality of its values and diversity, in accordance with the Elucidation of Article 41 paragraph (1) letter a of the Bali Provincial Regulation No. $1 / 2017$. So that on the basis of this conservation is an effort in maintaining the function of environmental sustainability.

As a constitutional basis in the 1945 Constitution of the Republic of Indonesia, Article 33 paragraph (3) which states that the existence of the earth, water and natural resources contained therein are controlled by the state and used for the greatest prosperity of the people. In connection with the appointment of the Bali Provincial Government (hereinafter referred to as the Bali Provincial Government) as the manager of the maritime conservation area in the waters of Benoa Bay in the Ministerial Decree No. 46/2019, and in accordance with Article 57 paragraph (5) of the PPLH Law which states "further provisions regarding conservation are regulated by Government Regulation (PP)", where until now there has not been any form of specific regulation regarding maritime conservation, as well as the Provincial Government. Bali also has yet to regulate policies regarding the management of the Benoa Bay maritime

\footnotetext{
${ }^{13}$ Muhammad Nizar Kherid en Aminah Aminah, "INTEGRASI KONSEP KONSERVASI LAUT MENJADI PERTAHANAN LAUT DALAM PENEGAKAN HUKUM LAUT PERSPEKTIF BIOSENTRISME", Law Reform 15, no 2 (n.d.): 258-74.
} 
conservation area as the basis for law enforcement in the management of the Benoa Bay maritime conservation area. With the absence of a legal policy regarding the management of the Benoa Bay maritime conservation area in the waters of the Province of Bali, this has resulted in a vacuum in legal norms in terms of the sustainability of special regulations regarding legal rules in managing the Benoa Bay maritime conservation area. So that in terms of formulating and stipulating management plans and zoning regulations for maritime conservation areas, designation of organizations, setting boundaries, socialization and stabilization of management have not been implemented properly because there is no government regulation of Bali Province which regulates.

Referring to the provisions of PERMEN KP No: PER.17/MEN/2008 concerning Conservation Areas in Coastal Areas and Small Islands, regarding the management of maritime conservation areas in Article 26 which principally regulates the management of maritime conservation areas within the scope of provincial areas, district/city implemented by the relevant local government. So it is very necessary to regulate in the form of the Bali Provincial Regulation regarding the management of the Benoa Bay maritime conservation area in the waters of Bali Province, in order to ensure legal certainty and sustainability in environmental preservation. Of course, by applying the theory of the value of public policy which is able to receive criticism, especially from the community in the process of making all public policies.

\subsection{Determination of Benoa Bay Conservation Area in the Effectiveness of Environmental Maintenance}

Obtaining the right to a good, proper and healthy environment is a form of human rights formulated in the 1945 Constitution of the Republic of Indonesia. The environment is a very valuable asset by producing various resources that can meet human needs, so that it can play a role in the welfare of society. ${ }^{14}$ Something that cannot be separated and greatly affects the lives of all living things is the environment itself. However, at present, the environmental condition has suffered a lot of damage due to the lack of human attitudes and characteristics and the inability to understand the role of the surrounding natural environment. 15

The majority of Balinese people who embrace Hinduism are always committed to maintaining the cultural heritage of their ancestors, namely in the form of traditions and legal regulations. The entire cultural heritage is based on Hindu religious beliefs in the Tri Hita Karana which contains the balance of the relationship between humans and God, humans and fellow humans, and humans and their environment. 16 In this regard, preserving the environment is an obligation that we must do for the sake of creating environmental sustainability, and for the sake of our present life until later we pass on to our children and grandchildren in the future, based on the 14 (fourteen) principles in Article 2 of the PPLH Law, the author emphasizes more on these 6 (six) principles as the basis for effectiveness in environmental maintenance related to the conservation of the Benoa Bay maritime area, namely:

\footnotetext{
${ }^{14}$ Gde Agus Erry Sukresna Arna, “Kewenangan Pemerintah Provinsi Bali Dalam Pemberian Hibah Kepada Desa Pakra man", Jurnal Magister Hukum Udayana (Udayana Master Law Journal) 5, no 3 (2016): 573-90.

15 Yustina Niken Sharaningtyas, "Gugatan Warga Negara (Citizen Law Suit) dan Justiciability Pemenuhan Hak Atas Lingkungan Hidup Yang Baik Dan Sehat", Kertha Patrika 38, no 1 (2016). 16 I Nyoman Adi Susila Op.cit, p. 479
} 
1. The principle of sustainability, by improving the quality of the environment for the sustainability of generations;

2. The principle of harmony and balance, where all the supporting aspects must be able to create a good environmental utilization;

3. The principle of ecoregion, taking into account the characteristics of the natural resources themselves;

4. The principle of local wisdom, of course by not forgetting the noble values that have become the habit of the community;

5. The principles of good governance, applying the principles of just governance with participation, transparency, efficiency and accountability; and

6. The principle of regional autonomy, the regional government has the authority to manage as well as protect the environment in accordance with the specificity and diversity of the region.

In accordance with Article 57 of the PPLH Law regarding environmental preservation, it can be carried out by means of natural resource conservation, one of which is maritime conservation in accordance with Kepmen-KP No. 46/2019, apart from being a positive response to the Letter of the Governor of Bali Province Number: 523.32/1687/KL/DISLAUTKAN regarding the Proposal for the Establishment of a Benoa Bay Maritime Conservation Area, it is also in the context of implementing the provisions of Article 23 PERMEN KP No: PER.17/MEN/2008. The definition of conservation of coastal areas and small islands in Article 1 point 7 Regulation of the Minister of Marine Affairs and Fisheries Number 17 of 2008 (hereinafter referred to as Permen KP No. 17/2008), namely efforts to protect, conserve, and also make good use of coastal areas and Small islands and their ecosystems to ensure the existence, availability, and sustainability while maintaining and increasing the quality of value and diversity. Resources originating from the oceans, both living and non-living, such as fish and other marine biota, coral reefs with high economic value biological wealth, oil, natural gas and minerals, and the sea can of course be used as a destination. water tourism which is very attractive and has a high selling value in the realm of tourism. ${ }^{17}$

Environmental law enforcement as a last resort in policy planning, according to the sequence of stages, namely: 1). Legislation, 2). Standardization determination, 3). Granting of permits, 4). Embodiment, 5). Law enforcement. Due to the absence of a legal rule in the form of a Bali Provincial Regulation regarding policies in the management of the Benoa Bay maritime cultural protection area, the authors refer to the related regulations, namely the PPLH Law and the KP Regulation No. 17/2008. It is hoped that the determination of the Benoa Bay maritime conservation area can be carried out effectively in the context of preserving the environment. The PPLH Law regulates that environmental preservation can be implemented in efforts to conserve natural resources, which is contained in Article 57 paragraph (1) letter a. The purpose of stipulating the conservation is to provide references guidelines for preserving, protecting and utilizing coastal areas and small islands and their ecosystems, as stated in Article 2 paragraph (1) Permen KP No. 17/2008, where these things are efforts to preserve the environment, especially coastal areas. Conservation is an activity that is considered to provide assurance in the efficient use of natural resources found in

17 Dian Khoreanita Pratiwi, "KEAMANANAN LAUT WILAY AH PERBATASAN INDONESIA SEBAGAI BENTUK PENJAGAAN KEDAULATAN NEGARA”, Supremasi Jurnal Hukum 3, no 1 (2020). 
coastal areas and small islands in an environmentally friendly manner, and can generate economic benefits for current and future generations.

In order for the Benoa Bay maritime conservation area to function effectively in the context of environmental preservation, it is hoped that maritime conservation must be capable to:

1. Maintaining and protecting the waters of Benoa Bay which are of high value so that they are not destroyed, shifted, replaced or extinct;

2. Reviving the function of Benoa Bay waters as an area that has high value functions and benefits for the sustainability of the ecosystem in it, and supports the activities of the surrounding community as a source of livelihood, traditional activities, religious ceremonies, and so on;

3. Protecting the waters of Benoa Bay from various damages caused by negative factors, especially those caused by humans;

4. Maintaining sustainability and of course increasing the quality of value and diversity contained in the waters of Benoa Bay;

5. Maintaining and preserving the environmental functions in the waters of Benoa Bay, so that future generations can still enjoy its beauty and are beneficial for survival.

Climate change adaptation and mitigation is another function of a conservation area, which is very helpful in increasing the resilience of the surrounding ecosystems against climate change. In addition to this, of course, there is also a need for protection and preservation activities that can be carried out by preventing and limiting activities that have a negative/detrimental impact on the integrity of customs and culture in the waters of Benoa Bay, do not forget to always help develop and advance aspects of sustainability culture and customs through religious ceremonial activities in Hinduism in particular, as well as other religions as a form of environmental maintenance.

\section{Conclusion}

The regulation regarding the Benoa Bay maritime conservation area which is managed by the Bali Provincial Government is still in a norm vacuum, where the Bali Provincial Government has not yet issued a legal policy in the form of a Bali Province regional regulation which further regulates regional management related to the protection of the Benoa Bay maritime culture at The waters of the Province of Bali are in accordance with the mandate of the Ministerial Decree No. KP. 46/2019. In this case, a regional regulation is urgently needed to further regulate the management of the Benoa Bay maritime conservation area so that Benoa Bay conservation activities can be realized immediately and obtain legal certainty in terms of its implementation. It is hoped that the determination of the Benoa Bay maritime conservation area can function effectively in the framework of preserving the environment, especially in the waters of Benoa Bay, where the maritime conservation of Benoa Bay must be able to ensure the wise use of its natural resources so that the availability of these natural resources remains. By always carrying out activities that have an effect on improving the quality of values and diversity of natural resources, as an effort to participate in preserving environmental functions and minimizing damage and pollution caused by human actions. So that gradually it will have an impact on restoring natural conditions that 
were previously damaged into an environment that increasingly provides benefits for the welfare of the lives of living things in it.

\section{Suggestion}

The Provincial Government of Bali is expected to immediately formulate a legal policy related to the Bali Provincial Regulation regarding regulations regarding the provisions in the management of the Benoa Bay maritime conservation area as a derivative of the mandate of the Ministerial Decree-KP No.46/2019, so that legal certainty will be created as the basis for appropriate implementation, integrated and systematic in terms of the management of the maritime cultural protection area of Benoa Bay which is expected to be able to function effectively in the framework of preserving the environment.

\section{References}

“13 Alasan Tolak Reklamasi Teluk Benoa - ForBALI", n.d.

Adiarsa, Dikdik. "Efektivitas Tata Hutan Di Kawasan Hutan Lindung Gunung Seraya Dalam Upaya Mengakomodir Kepentingan Religi". Kertha Patrika 40, no 01 (2018): 24-36.

Arna, Gde Agus Erry Sukresna. "Kewenangan Pemerintah Provinsi Bali Dalam Pemberian Hibah Kepada Desa Pakraman". Jurnal Magister Hukum Udayana (Udayana Master Law Journal) 5, no 3 (2016): 573-90.

Hidayatullah, Syukri. "STANDARDISASI INDUSTRI NASIONAL DALAM MEWUJUDKAN PEMBANGUNAN BERKELANJUTAN". Kertha Patrika 38, no 2 (n.d.).

Hr, Ridwan. "Hukum administrasi negara”. Jakarta: Raja Grafindo Persada, 2006.

Kherid, Muhammad Nizar, en Aminah Aminah. "INTEGRASI KONSEP KONSERVASI LAUT MENJADI PERTAHANAN LAUT DALAM PENEGAKAN HUKUM LAUT PERSPEKTIF BIOSENTRISME". Law Reform 15, no 2 (n.d.): 25874.

Meinarni, Ni Putu Suci. "PENYELESAIAN SENGKETA PENCEMARAN LINGKUNGAN LAUT DALAM KASUS TUMPAHAN MINYAK MONTARA DI LAUT TIMOR". Jurnal Magister Hukum Udayana (Udayana Master Law Journal) 5, no 4 (2016): 833-70.

Nugroho, Iwan. “Nilai-nilai Pancasila sebagai falsafah pandangan hidup bangsa untuk peningkatan kualitas sumber daya manusia dan pembangunan lingkungan hidup". Jurnal Konstitusi 3, no 2 (2010).

Pratiwi, Dian Khoreanita. "KEAMANANAN LAUT WILAYAH PERBATASAN INDONESIA SEBAGAI BENTUK PENJAGAAN KEDAULATAN NEGARA". Supremasi Jurnal Hukum 3, no1 (2020).

Rahmah, Syifaur. "PERLINDUNGAN HUKUM TERHADAP HAK MASYARAKAT NELAYAN WILAYAH PESISIR". Dinamika: Jurnal Ilmiah Ilmu Hukum 25, no 10 (2019).

Sharaningtyas, Yustina Niken. "Gugatan Warga Negara (Citizen Law Suit) dan Justiciability Pemenuhan Hak Atas Lingkungan Hidup Yang Baik Dan Sehat". Kertha Patrika 38, no 1 (2016).

Stewart, Richard, en James E Krier. "Environmental Law and Policy, New York: The Bobbs Merril Co". Indianapolis, hlm, 1978, 3-5.

Suantika, Wayan. “Resistensi Masyarakat Lokal terhadap Kapitalisme Global: Studi 
Kasus Reklamasi Teluk Benoa Bali Tahun 2012-2013". Jurnal Hubungan Internasional, 2015,55.

Susila, I Nyoman Adi. "Pengaturan Kawasan Suci Pantai Dalam Penyediaan Sarana Wisata Tirta Di Provinsi Bali". Jurnal Magister Hukum Udayana (Udayana Master Law Journal) 6, no 4 (2017): 478-88.

\section{Laws and Regulations}

Constitution of the Republic of Indonesia Year 1945 (fourth amendment).

Law of the Republic of Indonesia Number 32 of 2009 concerning Environmental Protection and Management. State Gazette of the Republic of Indonesia of 2009 Number 140.

Presidential Regulation of the Republic of Indonesia Number 51 of 2014 concerning Amendments to Presidential Regulation Number 45 of 2011 concerning Urban Spatial Plans for Denpasar, Badung, Gianyar, and Tabanan areas. State Gazette of the Republic of Indonesia of 2014 Number 121.

Regulation of the Minister of Marine Affairs and Fisheries of the Republic of Indonesia Number PER.17/MEN/2008 concerning Conservation Areas in Coastal Areas and Small Islands.

Decree of the Minister of Marine Affairs and Fisheries of the Republic of Indonesia Number 46/KEPMEN-KP/2019 concerning the Benoa Bay Maritime Conservation Area in the Waters of the Province of Bali.

Bali Provincial Regulation Number 1 of 2017 concerning Environmental Protection and Management. Bali Provincial Gazette of 2017 Number 1. 